\title{
Maximising porosity for flow units evaluation in sandstone hydrocarbon reservoirs (A Case Study of Ritchie's Block, Offshore Niger Delta)
}

\author{
Abraham-A. M. Richardson ${ }^{1}$ and Fabio Taioli ${ }^{2}$ \\ ${ }^{I}$ Researcher at Institute of Energy and Environment (IEE), University of Sao Paulo (USP), Brazil. \\ ${ }^{2}$ Professor at Institute of Energy and Environment (IEE), University of Sao Paulo (USP), Brazil
}

\begin{abstract}
Herein the relationships between porosity $(\Phi)$ and permeability $(K)$, reservoir quality index $(R Q I)$ and flow zone indicator (FZI) were further verified and used to evaluate the selected reservoirs. This work is aimed at presenting porosity dependent equations for formation evaluation, through; (a) modification of traditional equations and (b) generation of curves/models for the estimation of $K, R Q I$ and FZI based on three fundamental ideas to aid the evaluation of the reservoirs flow units. Two reservoirs $(R-M$ and $R-N)$ were correlated across three wells $\left(R-D_{a}, R-D_{b}\right.$ and $\left.R-D_{c}\right)$ in Ritchie's Block, offshore Niger Delta. The equations (Tixier's, Timur's and Coates') for K determination and the expressions for RQI and FZI were modified and used for the evaluation of hydrocarbon potential of the two reservoirs mapped across the selected wells. Three porosity dependent equations suggested for use in sandstone units were presented for each of K, RQI and FZI. These equations were used to evaluate and compare these parameters each in three different ways and suggest that the reservoirs have good flow units. The estimated average porosity of the two reservoirs is 0.24, consequently, the values of averaged $K$ were estimated at $1721 \mathrm{mD}, 2343 \mathrm{mD}$ and $1969 \mathrm{mD}$ for $K_{m t x}, K_{m t m}$ and $K_{m c}$ respectively. Similarly, the corresponding values of RQI and FZI were estimated at $2.66 \mu \mathrm{m}, 3.10 \mu \mathrm{m}$ and $2.84 \mu \mathrm{m}\left(R Q I_{a a}, R Q I_{a b}\right.$ and $R Q I_{a c}$ ) and $8.42 \mu \mathrm{m} 9.82 \mu \mathrm{m}$ and $9.01 \mu \mathrm{m}\left(F Z I_{a a}, F Z I_{a b}\right.$ and $F Z I_{a c}$ ) respectively. Models in form of curves that show the relationships between the evaluated parameters and porosity were presented. In a way to combine the three expressions for each of the parameters, the average of the values for $R Q I_{a a}, R Q I_{a b}$ and $R Q I_{a c}$ and the average of the corresponding values for $F Z I_{a a}, F Z I_{a b}$ and $F Z I_{a c}$ were determined. Hence, $R Q I_{\text {average }}$ and $F Z I_{\text {average }}$ were plotted against porosity to help generate a combined quick-look model for RQI and FZI prediction. With this model, the porosity of 0.24 corresponds to RQI of $2.95 \mu \mathrm{m}$ and FZI of $9.00 \mu \mathrm{m}$ respectively. Overall, the evaluated reservoirs were confirmed to have hydrocarbon with very good values of $K, R Q I$ and FZI. Significant rates of hydraulic conductivity and hydrocarbon recoveries are anticipated within the reservoirs $(R-M$ and $R-N)$ across the three wells and as such, hydrocarbon volumetric estimation is encouraged. A sensitivity analysis was carried out and shows that the change in tortuosity factor does not seem to have a significant influence on the results. Therefore, an averaged tortuosity factor of 0.8 was used in the equations. The expressions were also tested and compared with the results computed using the traditional equations and similar values were obtained.
\end{abstract}

Keywords: Hydrocarbon potential, Permeability (K), Reservoir Quality Index (RQI), Flow Zone Indicator (FZI)

\section{Introduction}

The relationship between porosity and flow units in the sandstone reservoirs in Ritchie's oil block, located in the offshore part of the southern Niger Delta, Nigeria has been evaluated. Porosity is an influential parameter in the petrophysical and volumetric evaluation and the majority of the reservoirs physical characteristics are not completely expressed without the use of porosity. The relationship between porosity and reservoir's flow units is very effective for explaining reservoirs' geological attributes such as grain sizes and sorting, shale content, cementation, consolidation of rocks, pore sizes and interconnectivity among others $[1 ; 2 ; 3]$. In most cases involving qualitative evaluations, a few other parameters such as formation factor $(\mathrm{F})$, irreducible water saturation $\left(\mathrm{S}_{\text {wirr }}\right)$ and free fluid index (FFI) are calculated first using porosity and a few other factors as inputs before calculating permeability and other parameters.

This work presents modified expressions with which permeability (K), reservoir quality index (RQI) and flow zone indication (FZI) were evaluated. Essential parameters for reservoirs qualitative evaluations are derivable from wire-line logs $[3 ; 4]$ and porosity is always incorporated with other information from the seismic analysis for volumetric estimations [5; 6; 7]. Therefore, it is very important that porosity be carefully estimated before it is optimised for formation evaluation. The determination of the reservoirs porosity was done with the aid of density $\log (\mathrm{RHOB})$ and the values obtained were corrected for the influence of shale before they were used for the evaluation of other dependent parameters. The correction for shale influence on the porosity of the reservoirs' sand is very important $[8 ; 9]$ because any error in the evaluation or computation of porosity could result in either exaggeration or reduction of the actual value of the dependent parameters. Since whole lots of parameters use for 
formation evaluation are directly or indirectly dependent upon porosity, when it is well calculated and properly harnessed, it will present a way of minimising risk. In volumetric estimations, for instance, every other parameter been alright, 0.05 to $0.1(5-10 \%)$ increase or decrease in porosity value could result in a notable increase or decrease in the computed volumes of hydrocarbons in place. As such, the actual volume is either reduced or exaggerated and could affect the final decision. Similarly, in qualitative evaluations, the expression for RQI [2] is dependent upon $\mathrm{K}, \mathrm{K}$ is dependent upon $\mathrm{S}_{\text {wirr }}$ and/or FFI, both $\mathrm{S}_{\text {wirr }}$ and FFI are dependent upon $\mathrm{F}$ while $\mathrm{F}$ is dependent upon $\Phi$. If one must follow the computation in steps from the determination of $\mathrm{F}$, $\Phi$ will be approximated over a range of equations, because most of these equations never give their results in whole figures. Errors due to estimation are always undesirable, especially when it comes to volumetric analysis and other decision dependent calculations, where overestimation or underestimation error as low as \pm 0.05 can result in a notable difference. This can bring about risk and uncertainty.

Therefore, this work tends to look at the use of equations that are involving direct computation of porosity for the evaluation of some of the reservoirs intrinsic parameters in sandstone units. The possibility of using porosity as the only variable in these expressions was fundamental because it assisted in drawing a direct relationship between porosity and the evaluated parameters (K, RQI and FZI). Curves showing the relationship between porosity and each of K, RQI and FZI based on the three different ideas (Tixier's, Timur's and Coates') were presented. A single model for the determination of RQI and FZI based on the modified expressions was also presented. These curves are recommendable for use as quick-look models in the estimation of these parameters, provided porosity values are available.

\section{Study location and geology}

The study location (Latitude $3.6^{\circ} \mathrm{N}$ and $3.8^{\circ} \mathrm{N}$ and longitude $7.1^{\circ} \mathrm{E}$ and $7.3^{\circ} \mathrm{E}$ ) is within the offshore region of the southern Niger Delta (Fig. 1). The offshore boundary of the Niger Delta province is bound by the Cameroon volcanic line to the east, the Dahomey basin to the west and the $2 \mathrm{~km}$ sediment thickness contour or the $4000 \mathrm{~m}$ bathymetric contour to the south and south-west $[10 ; 11]$.

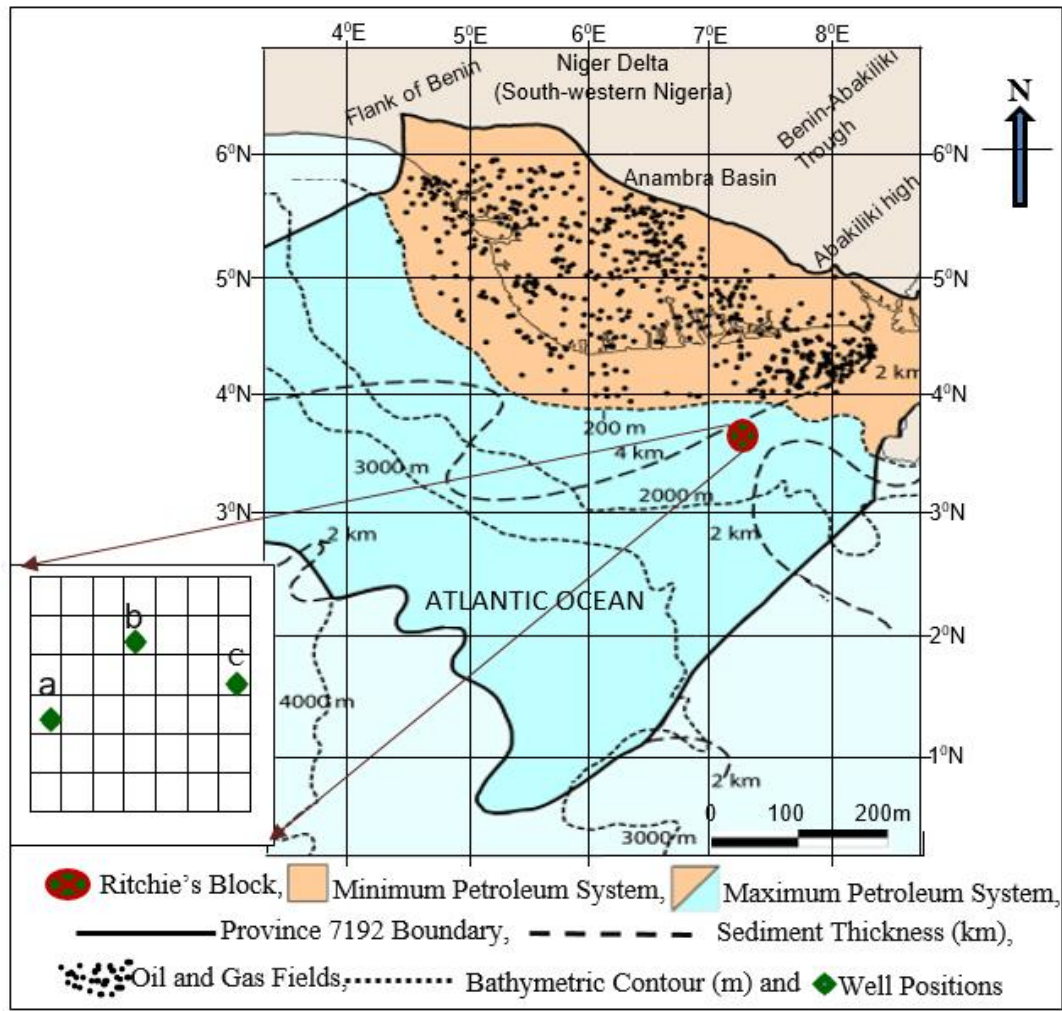

Figure 1. Index map of study location and map of Niger Delta showing the petroleum systems and oil and gas fields, modified from Petroconsultant [10]

Deep-sea landscapes and related structural alterations are believed to have emerged due to activities involving erosion, sedimentation and gravity influenced tectonics $[12 ; 13 ; 14 ; 15]$. These events have assisted in redefining the seabed bathymetry and the collective petroleum pattern of the region. The rollovers structures collapsed crests, faults with back-to-back features and the marine shale diapers which provided the sealing mechanism for the reservoirs are also linked with these structural deformations [16; 17; 18; 19]. Although, stratigraphic traps are not impossible but most known traps in Niger Delta fields are structural and they believed 
to have developed during synsedimentary deformation of the Agbada parallel $[17 ; 20]$. The onshore Province is delineated by the geology of southern Nigeria and southwestern Cameroon. The northern boundary is the Benin flank, an east-northeast trending hinge line south of the West Africa basement massif [11]. The northeastern boundary is defined by outcrops of the Cretaceous on the Abakaliki High and further southeast by the Calabar flank. The province covers $300,000 \mathrm{~km}^{2}$ and includes the geologic extent of the Tertiary Niger Delta (AkataAgbada) Petroleum System $[11 ; 16]$.

The Niger Delta is characterised by three geologic formations; Benin, Agbada and Akata. Benin Formation consists of highly porous continental sands and gravels with very little hydrocarbon. The abundance of hydrocarbon in Niger Delta is mostly associated with the Agbada and Akata Formations. Agbada Formation is between the Benin and the Akata Formations and consists of a sandy part, which serves as the main hydrocarbon reservoir of the delta and shale as the cap rock. The Akata Formation is believed $[16 ; 20 ; 21]$ to have the highest field with the lowest gas to oil ratio. The Agbada Formation has intervals that contain organic carbon contents sufficient to be considered good source rocks [22; 23]. But Evamy et al [20] and Starcher [17] believe that the intervals, rarely reach thickness sufficient to produce a world-class oil province and are immature in various parts of the delta. Similarly, the marine interbedded shale in the Agbada Formation, the marine Akata shale, and Cretaceous shale are also suspected to be contributing source rocks [20;24;25;26]. Evamy et al. [20] supported the marine shale (Akata Formation) and the shale interbedded with paralic sandstone (lower Agbada Formation) as the source rocks for the Niger Delta oils.

\section{Materials and Methods}

Gamma-ray $\log (\mathrm{GR})$, deep laterolog (LLD), water saturation $\log$ (SW), neutron porosity $\log$ (NPHI) and density tool (ROHB) were engaged in this work. The basic methods herein are:

(a) modification of traditional (Timur's Tixier's and Coates') permeability (K) equations to help provide alternative expressions in sandstone units;

(b) sensitivity analysis on the expressions in (a) above using different values of tortuosity factor to help verify the influence of its change on permeability;

(c) redefinition of the permeability (K) equations using the idea derived from (b) above and modification of reservoir quality index (RQI) and flow zone indicator (FZI);

(d) determination of porosity from well logs to aid the computation of K, RQI and FZI of the selected reservoirs with the aid of the equations as in (c) above;

(e) generation of curves showing permeability/porosity, reservoir quality index/porosity and flow zone indicator/porosity relationships based on the results as in (d) above and

(f) determination of RQI $I_{\text {average }}$ and $\mathrm{FZI}_{\text {average }}$ based on the three expressions for each of them, to help generate a combined model for the estimation of the reservoirs flow units.

\subsection{Modification of Timur's, Tixier's and Coates' permeability (K) expressions for use in sandstone units}

The normal expression for irreducible water saturation is given by equation 1 .

$$
\left(S_{\text {wirr }}\right)^{2}=\frac{\mathrm{F}}{2000}
$$

Where; $2000=$ formation constant and $\mathrm{F}=$ formation factor which is expressed by equation 2 .

$$
\mathrm{F}=\frac{\mathrm{a}}{\Phi^{\mathrm{m}}}
$$

[a $=$ tortuosity factor (usually within the range of 0.6 to 1 ), $\Phi=$ porosity and $\mathrm{m}=$ porosity exponent $]$

Hence, the expression for irreducible water saturation can be written as equation 3 .

$$
\left(S_{\text {wirr }}\right)^{2}=\frac{a}{2000 \Phi^{m}}
$$

But porosity exponent $(\mathrm{m})$ is usually taken as 2 in sandstone units. Therefore;

$$
\left(S_{\text {wirr }}\right)^{2}=\frac{a}{2000 \Phi^{2}}
$$

Such that irreducible water saturation in sandstone units can be expressed by equation 5 .

$$
S_{\text {wirr }}=\frac{a^{0.5}}{44.72 \Phi}
$$

Where 44.72 is the square root of 2000 .

This equation was then used to modify Tixier's, Timur's and Coates' equations for permeability.

The Tixier's equation [1] for permeability is given by equation 6 .

$$
K^{0.5}=250 \frac{\Phi^{3}}{s_{\text {wirr }}}
$$

$S_{\text {wirr }}$ is substituted in equation 6 using equation 5 such that, the expression becomes;

$$
K^{0.5}=250 \frac{\Phi^{3}}{1} \div\left\lceil\frac{a^{0.5}}{44.72 \Phi}\right\rceil
$$


Hence,

$$
K^{0.5}=250 \frac{\Phi^{3}}{1} \times\left\lceil\frac{44.72 \Phi}{a^{0.5}}\right\rceil
$$

Therefore, the Tixier's permeability expression is modified for use in sandstone units as equation 9.

$$
\left(K_{m t x}\right)^{0.5}=\frac{11180 \Phi^{4}}{a^{0.5}}
$$

$\left[K_{m t x}\right.$ is permeability modified from Tixier's expression].

The expression for permeability [1] given by Timur is written as;

$$
K^{0.5}=100 \frac{\Phi^{2.25}}{s_{\text {wirr }}}
$$

Similarly, $s_{\text {wirr }}$ is substituted such that, the Timur's permeability expression is modified for use in sandstone units as equation 11 .

$$
\left(K_{m t m}\right)^{0.5}=\frac{4472 \Phi^{3.25}}{a^{0.5}}
$$

[ $K_{m t m}$ is permeability modified from Timur's expression].

Schlumberger [1] stated Coates' expression for permeability as equation 12.

and

$$
K^{0.5}=70 \frac{\Phi^{2}\left(1-s_{\text {wirr }}\right)}{s_{\text {wirr }}}
$$

Such that

$$
K^{0.5}=70 \Phi^{2}\left[1-\frac{a^{0.5}}{44.72 \Phi}\right] \div\left[\frac{a^{0.5}}{44.72 \Phi}\right]
$$

Consequently,

$$
K^{0.5}=70 \Phi^{2}\left[\frac{44.72 \Phi-a^{0.5}}{44.72 \Phi}\right] \div\left[\frac{a^{0.5}}{44.72 \Phi}\right]
$$

$$
K^{0.5}=70 \Phi^{2}\left[\frac{44.72 \Phi-a^{0.5}}{44.72 \Phi}\right] \times\left[\frac{44.72 \Phi}{a^{0.5}}\right]
$$

Hence, the Coates' permeability expression is modified for use in sandstone units as equation 16.

$$
\left(K_{m c}\right)^{0.5}=\frac{3130.4 \Phi^{3}-70 \Phi^{2} a^{0.5}}{a^{0.5}}
$$

[ $K_{m c}$ is permeability modified from Coates' expression].

\subsection{Sensitivity analysis}

A simulation was carried out by doing a sensitivity analysis on $K_{m t m}, K_{m t x}$ and $K_{m c}$ considering the possible range ( 0.6 to 1.0 ) of tortuosity factor (a) and a porosity range of 0.05 to 0.75 . The results of $\mathrm{K}$ using each of $0.6,0.7,0.8,0.9$ and 1.0 with the three equations herein were plotted against porosity to help verify the influence of the change in the factor of tortuosity on permeability. The three expressions show approximately the same results as shown in Figure 2.

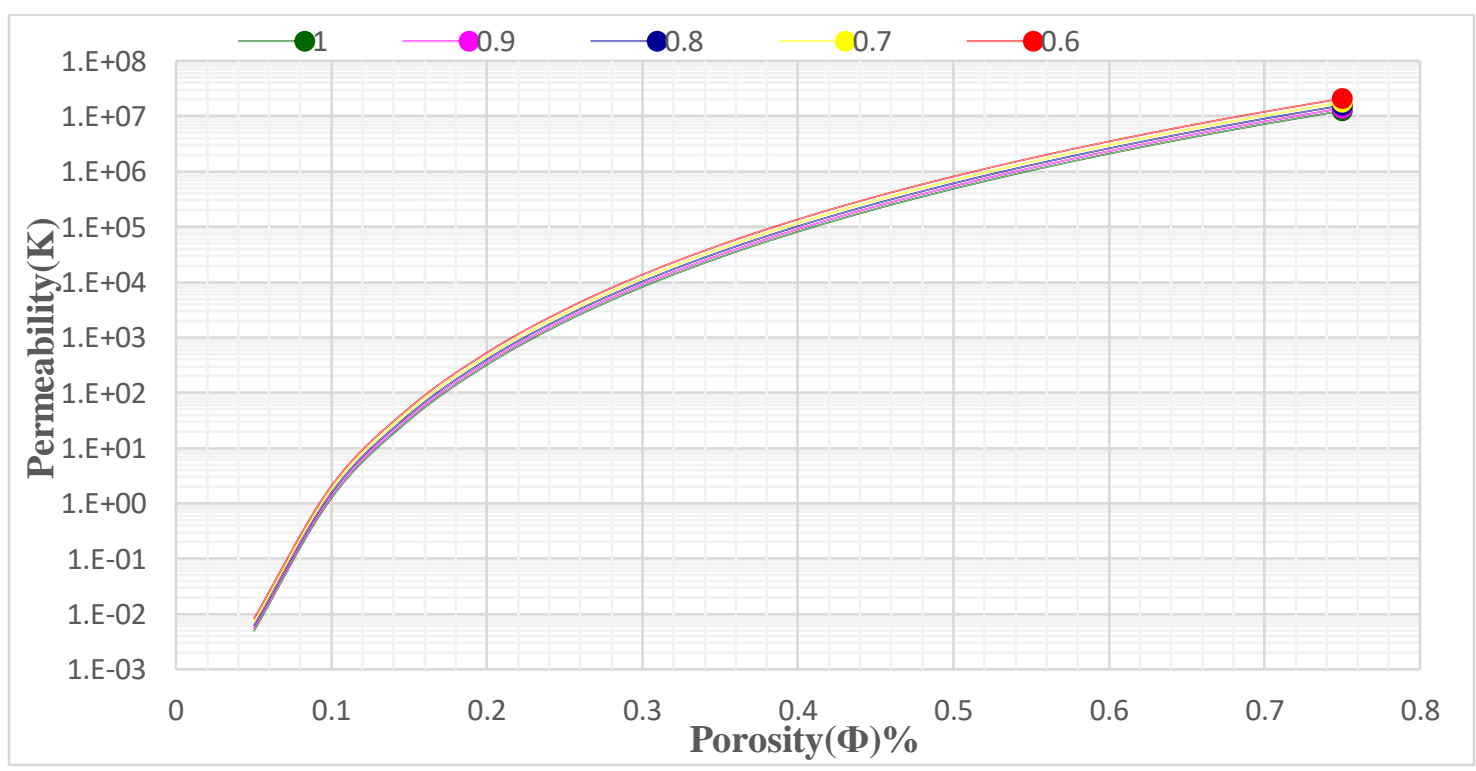

Figure 2: Curves showing the influence of the change in tortuosity factor (a) on permeability (k) 
The evaluation shows that change in tortuosity factor seems not to have a significant influence on the permeability values. Therefore, the average (0.8) of the range (0.6 to 1$)$ of tortuosity factor was used to redefine the equations for the reservoirs, such that only porosity dependent expressions were presented as shown in equations 15 to 18 .

Similarly,

$$
\begin{aligned}
& \left(K_{m t x}\right)^{0.5}=\frac{11180 \Phi^{4}}{(0.8)^{0.5}} \\
& \left(K_{m t x}\right)^{0.5}=\frac{11180 \Phi^{4}}{0.894}
\end{aligned}
$$

and

$$
\left(K_{m t m}\right)^{0.5}=\frac{4472 \Phi^{3.25}}{0.894}
$$

$$
\left(K_{m c}\right)^{0.5}=\frac{3130.4 \Phi^{3}-62.58 \Phi^{2}}{0.894}
$$

\subsection{Modification of equations for reservoir quality index (RQI) and flow zone indicator} (FZI) for the reservoirs sandstone units

The equation for RQI [2] is given by equation 21 .

$$
R Q I=0.0314\left(\frac{K}{\Phi}\right)^{0.5}
$$

This equation was redefined by substituting the value of $\mathrm{K}$ using equations 18, 19 and 20 respectively, such that;

Hence;

$$
R Q I_{a a}=\frac{351 \Phi^{4}}{0.894 \Phi^{0.5}}
$$

and

$$
R Q I_{a b}=\frac{140.4 \Phi^{3.25}}{0.894 \Phi^{0.5}}
$$

$$
R Q I_{a c}=\frac{98.29 \Phi^{3}-1.965 \Phi^{2}}{0.894 \Phi^{0.5}}
$$

Where; $R Q I_{a a}, R Q I_{a b}$ and $R Q I_{a c}$ are alternative expressions a, b and c for RQI, modified with $K_{m t x}, K_{m t m}$ and $K_{m c}$ respectively.

In the same vein, FZI was redefined in three different ways by using the three alternative expressions for RQI in equations 22, 23 and 24. The expression for FZI [2] is given by equation 25.

$$
F Z I=\frac{R Q I}{\Phi_{r}}
$$

Such that

Similarly,

$$
F Z I_{a a}=\frac{351 \Phi^{4}}{\left(0.894 \Phi^{0.5}\right) \Phi_{r}}
$$

$$
\begin{aligned}
& F Z I_{a b}=\frac{140.4 \Phi^{3.25}}{\left(0.894 \Phi^{0.5}\right) \Phi_{r}} \\
& F Z I_{a c}=\frac{\left(98.29 \Phi^{3}-1.965 \Phi^{2}\right)}{\left(0.894 \Phi^{0.5}\right) \Phi_{r}}
\end{aligned}
$$

Where; $F Z I_{a a}, F Z I_{a b}$ and $F Z I_{a c}$ are alternative expressions a, b and c for FZI, modified with $R Q I_{a a}, R Q I_{a b}$ and $R Q I_{a c}$ respectively. $\Phi_{r}$ is the ratio of the derived porosity and the difference between the maximum derivable value (100\%) of porosity and the derived porosity, it is expressed by equation 29.

$$
\Phi_{r}=\frac{\Phi}{1-\Phi}
$$

\subsection{Determination of porosity and computation of parameters (K, RQI and FZI) across the selected reservoirs}

This aspect started with log interpretation to help determine the average porosity of each of the reservoirs. Two reservoirs (R-M and R-N) were correlated across the three wells (R-D, R-D $D_{b}$ and R-D $)$ (Fig.3). Gamma-ray $\log (\mathrm{GR})$ was used to identify sandstone units while deep laterolog (LLD) was used to delineate hydrocarbon units within the sandstone reservoirs. Well R-Da does not have porosity tool but the signatures of GR, LLD and water saturation (SW) within the reservoirs in this well are in similar patterns with those in other selected wells $\left(R-D_{b}\right.$ and R-D $\mathrm{D}_{\mathrm{c}}$ ). Similarly, NPHI and RHOB also show similar responses within each of the correlated reservoirs in 
wells R-D $\mathrm{D}_{\mathrm{b}}$ and R-D (Fig.3) as such, it is assumed that the porosity values within the reservoir R-M and R-N in $\mathrm{R}-\mathrm{D}_{\mathrm{a}}$ should be within the same range as the other wells. In addition, the reservoirs in each of the wells are correlated across the same formation.

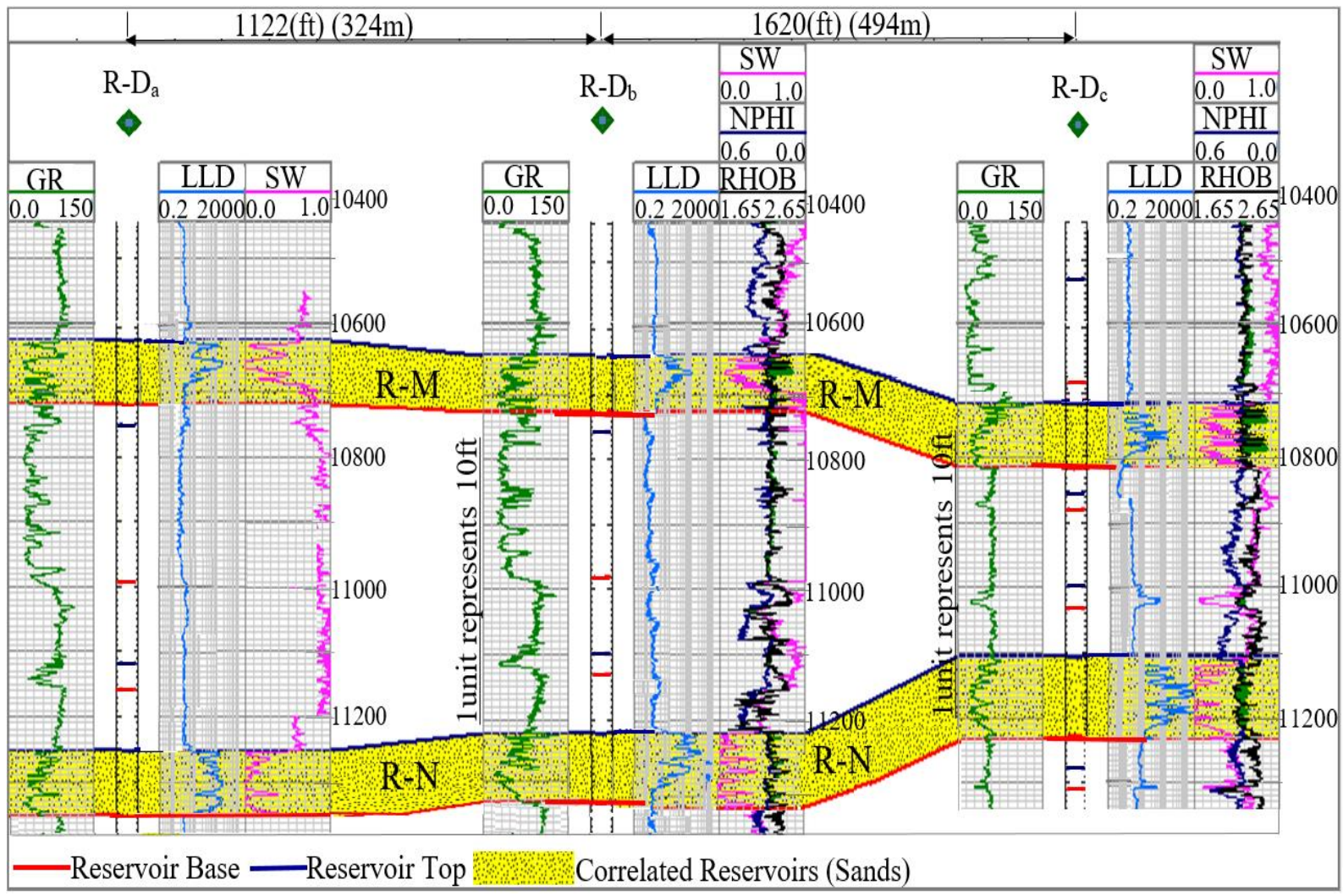

$G R=$ Gamma-ray log, $L L D=$ Deep laterolog, NPHI = Neutron Porosity log, $R O H B=$ Density tool, and $S W=$ Water Saturation Log

Figure 3. Well logs with correlated reservoirs

Therefore, porosity $(\Phi)$ values were obtained directly from density log (RHOB) at intervals of 10 feet and corrected for shale influence within each of the reservoirs using equation 30.

$$
\Phi_{D}=\frac{\rho_{m a}-\rho_{b}}{\rho_{m a}-\rho_{f}}-V_{s h}\left[\frac{\rho_{m a}-\rho_{s h}}{\rho_{m a}-\rho_{f}}\right]
$$

$\left[V_{s h}=\right.$ volume of shale, $\Phi_{D}=$ density derived porosity corrected for shale, $\rho_{m a}=$ matrix density of formation ( $2.65 \mathrm{gcc}$ for sandstone), $\rho_{b}=$ bulk density of formation, $\rho_{f}=$ fluid density of formation $(1.0 \mathrm{gm} / \mathrm{cc})$ and $\rho_{s h}=$ bulk density of adjacent shale].

Averaged porosity values within each reservoir were used as inputs to compute the reservoir permeability (K), reservoir quality index (RQI) and Flow Zone Indicator (FZI).

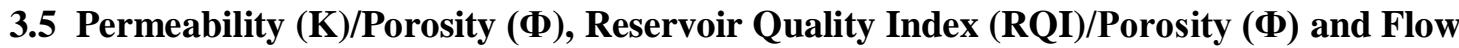 Zone Indicator (FZI)/ Porosity ( $\Phi)$ Curves}

With the aid of the expressions herein a range of values from 0 to $50 \%$ (0 to 0.50$)$ was used for porosity to compute K, RQI and FZI. The averaged values of these parameters across the selected reservoirs were extracted from the results, considering the averaged porosity values calculated for each reservoir. Based on the results, curves were generated by plotting each of the evaluated parameters against porosity. Similarly, the values of $\mathrm{RQI}_{\mathrm{a}}, \mathrm{RQI}_{\mathrm{ab}}$ and $\mathrm{RQI} \mathrm{I}_{\mathrm{ac}}$ were averaged with the corresponding values FZI $\mathrm{aa}_{\mathrm{a}}, \mathrm{FZI}_{\mathrm{ab}}$ and FZI $\mathrm{ac}_{\mathrm{ac}}$. RQI $\mathrm{average}_{\text {and }}$

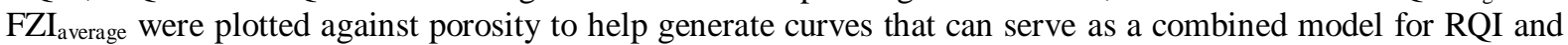
FZI estimations within sandstone units. 
Maximising Porosity for Flow Units Evaluation in Sandstone Hydrocarbon Reservoirs

\section{Results}

The results obtained for $\mathrm{K}, \mathrm{RQI}$ and FZI using averaged porosity within each of the reservoirs are presented in Tables 1 and 2.

Table 1: Results of the evaluated parameters across reservoir R-M

\begin{tabular}{|l|l|l|l|l|l|l|l|l|l|l|l|}
\hline Wells & $\Phi$ & $\mathrm{a}$ & $\begin{array}{c}K_{(m t x)} \\
(m D)\end{array}$ & $\begin{array}{c}K_{(m t m)} \\
(m D)\end{array}$ & $\begin{array}{c}K_{m c} \\
(m D)\end{array}$ & $\begin{array}{l}R Q I_{a a} \\
(\mu \mathrm{m})\end{array}$ & $\begin{array}{l}R Q I_{a b} \\
(\mu \mathrm{m})\end{array}$ & $\begin{array}{l}R Q I_{a c} \\
(\mu \mathrm{m})\end{array}$ & $\begin{array}{l}F Z I_{a a} \\
(\mu \mathrm{m})\end{array}$ & $\begin{array}{c}F Z I_{a b} \\
(\mu \mathrm{m})\end{array}$ & $\begin{array}{l}F Z I_{a c} \\
(\mu \mathrm{m})\end{array}$ \\
\hline$R-D_{a}$ & 0.24 & 0.80 & 1721 & 2343 & 1969 & 2.66 & 3.10 & 2.84 & 8.42 & 9.82 & 9.01 \\
\hline$R-D_{b}$ & 0.23 & 0.80 & 1225 & 1776 & 1513 & 2.29 & 2.76 & 2.55 & 7.67 & 9.24 & 8.53 \\
\hline$R-D_{c}$ & 0.24 & 0.80 & 1721 & 2343 & 1969 & 2.66 & 3.10 & 2.84 & 8.42 & 9.82 & 9.01 \\
\hline
\end{tabular}

Table 2: Results of the evaluated parameters across reservoir R-N

\begin{tabular}{|l|c|l|l|l|l|l|l|l|l|l|l|}
\hline Wells & $\Phi$ & $\mathrm{a}$ & $\begin{array}{c}K_{(m t x)} \\
(m D)\end{array}$ & $\begin{array}{c}K_{(m t m)} \\
(m D)\end{array}$ & $\begin{array}{c}K_{m c} \\
(m D)\end{array}$ & $\begin{array}{l}R Q I_{a a} \\
(\mu \mathrm{m})\end{array}$ & $\begin{array}{l}R Q I_{a b} \\
(\mu \mathrm{m})\end{array}$ & $\begin{array}{l}R Q I_{a c} \\
(\mu \mathrm{m})\end{array}$ & $\begin{array}{l}F Z I_{a a} \\
(\mu \mathrm{m})\end{array}$ & $\begin{array}{c}F Z I_{a b} \\
(\mu \mathrm{m})\end{array}$ & $\begin{array}{l}F Z I_{a c} \\
(\mu \mathrm{m})\end{array}$ \\
\hline$R-D_{a}$ & 0.24 & 0.80 & 1721 & 2343 & 1969 & 2.66 & 3.10 & 2.84 & 8.42 & 9.82 & 9.01 \\
\hline$R-D_{b}$ & 0.24 & 0.80 & 1721 & 2343 & 1969 & 2.66 & 3.10 & 2.84 & 8.42 & 9.82 & 9.01 \\
\hline$R-D_{c}$ & 0.25 & 0.80 & 2386 & 3054 & 2534 & 3.07 & 3.47 & 3.16 & 9.20 & 10.41 & 9.48 \\
\hline
\end{tabular}

The curves generated according to the equations herein are as shown in Figures 4, 5 and 6 .

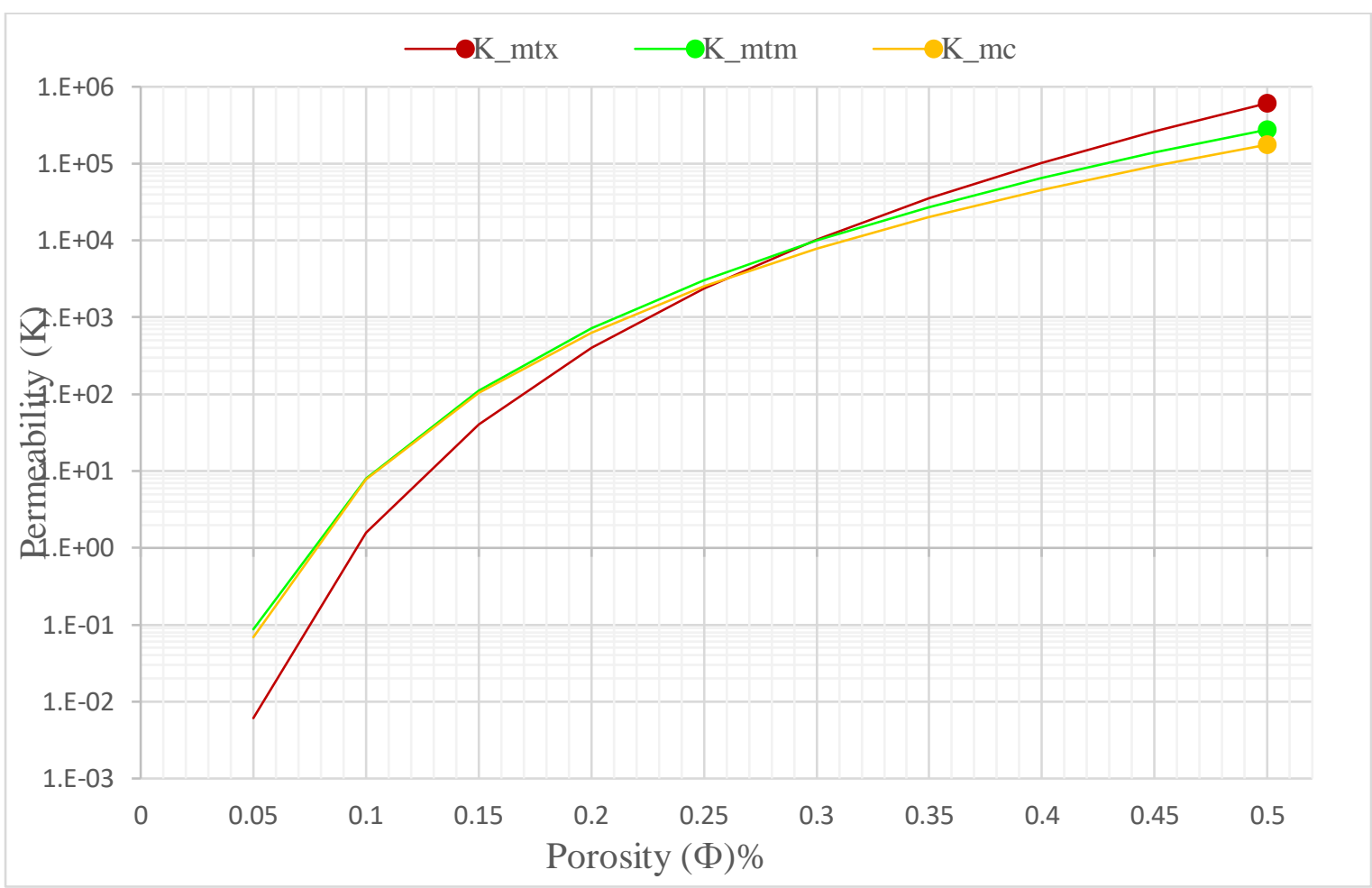

Figure 4: Permeability (K)/Porosity $(\Phi)$ curves 


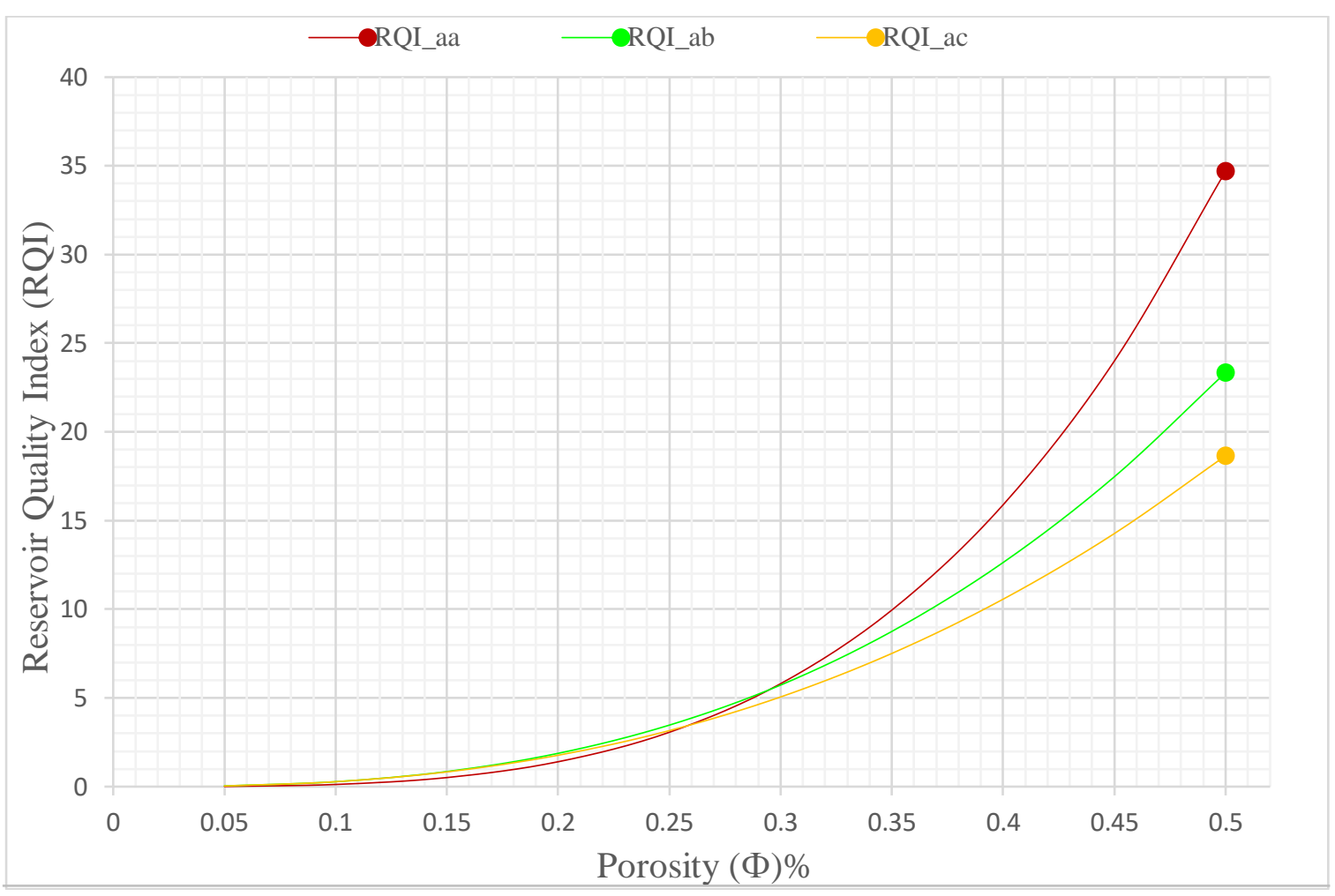

Figure 5: Reservoir Quality Index (RQI)/Porosity $(\Phi)$ curves

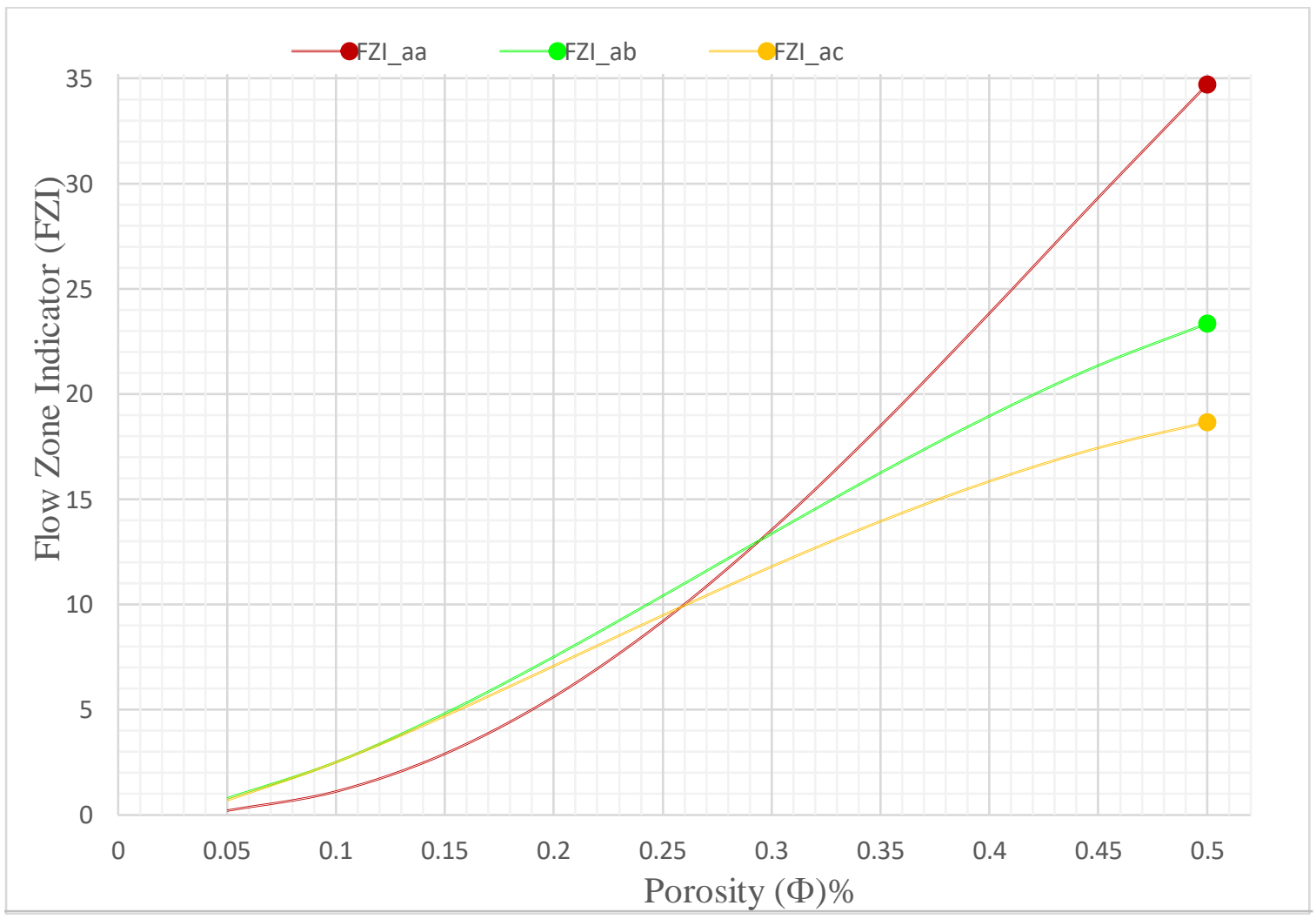

Figure 6: Flow Zone Indicator (FZI)/Porosity $(\Phi)$ curves 
The combined model for the estimation of reservoir quality index (RQI) and flow zone indicator (FZI) to aid the evaluation of the reservoirs flow units is as shown in Figure 7.

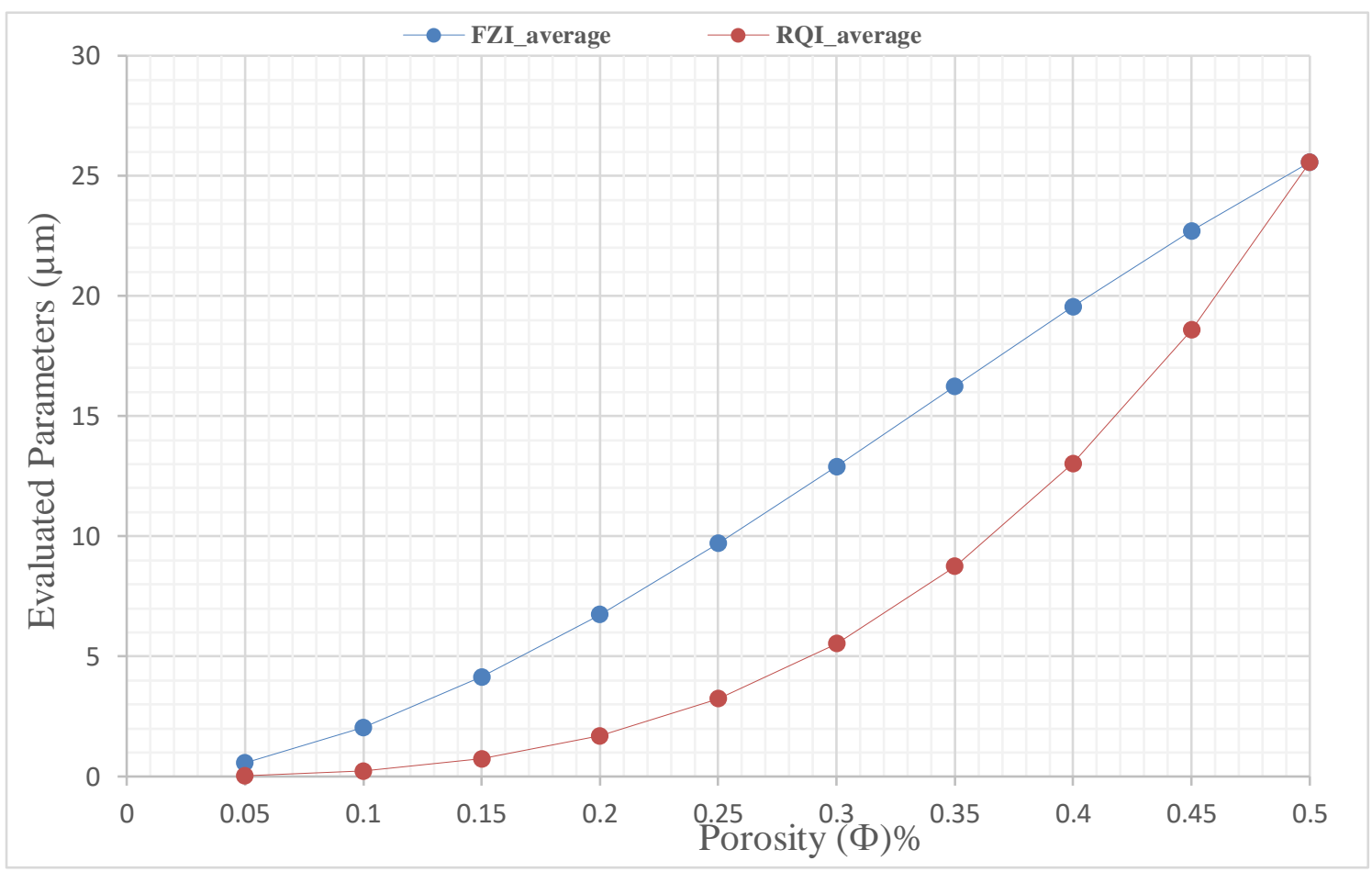

$\mathrm{RQI}_{\mathrm{average}}=$ Average of the values of $\mathrm{RQI} \mathrm{I}_{\mathrm{aa}}, \mathrm{RQI}_{\mathrm{ab}}$ and $\mathrm{RQI} \mathrm{I}_{\mathrm{ac}}$

$\mathrm{FZI}_{\text {average }}=$ Average of the values of $\mathrm{FZI}_{\mathrm{aa}}, \mathrm{FZI}_{\mathrm{ab}}$ and $\mathrm{FZI}_{\mathrm{ac}}$

Figure 7: Combined quick-look model for the prediction of RQI and FZI.

\section{Discussion}

Two hydrocarbon-bearing reservoirs (R-M and R-N), were identified and correlated across three wells (R-Da, R-Db and R-Dc). This study presents porosity dependent expressions for permeability (K), reservoir quality index (RQI) and flow zone indicator (FZI). Curves were generated based on these expressions and were used for the estimation of RQI and FZI to help predict flow units across the selected reservoirs. R-M shows averaged porosity of $0.24,0.23$ and 0.24 in R- $D_{a}, R-D_{b}$ and R- $D_{c}$, while R-N shows $0.24,0.24$ and 0.25 in R-D R- $D_{b}$ and R-Dc respectively. Such that, the average porosity of the two reservoirs across the three wells is $24 \%$. Based on this value, the average permeability values of the two reservoirs are $1721 \mathrm{mD}, 2343 \mathrm{mD}$ and $1969 \mathrm{mD}$ for $\mathrm{K}_{\mathrm{mtx}}, \mathrm{K}_{\mathrm{mtm}}$ and $\mathrm{K}_{\mathrm{mc}}$ respectively. Permeability above $1000 \mathrm{mD}$ (1Darcy) is very good and indicative of a formation with good flow units. Averaged values for reservoir quality index across the two reservoirs are $2.66 \mu \mathrm{m}, 3.10 \mu \mathrm{m}$ and $2.84 \mu \mathrm{m}$ for $\mathrm{RQI}_{\mathrm{aa}}, \mathrm{RQI}_{\mathrm{ab}}$ and $\mathrm{RQI} \mathrm{I}_{\mathrm{ac}}$ respectively. Similarly, average values for the flow zone indicator are $8.42 \mu \mathrm{m} 9.82 \mu \mathrm{m}$ and $9.01 \mu \mathrm{m}$ for $\mathrm{FZI}_{\mathrm{aa}}, \mathrm{FZI}_{\mathrm{ab}}$ and $\mathrm{FZI}_{\mathrm{ac}}$ respectively. However, with the aid of the combined model, at the porosity of $0.24 \mathrm{RQI}$ is $2.95 \mu \mathrm{m}$ while FZI is $9.00 \mu \mathrm{m}$.

FZI is directly proportional to RQI; therefore, significant values of RQI indicate good values of FZI. This implies that the sandstone reservoirs can be considered coarse-grained and well sorted with little volumes of shales. Consequently, the reservoirs are expected to present good pore throats. From the curves, the increase in porosity corresponds to increase in K, RQI and FZI, considering all the scenarios. Reservoirs with very good RQI and/or FZI usually seem to have significant hydraulic conductivity and very good recovery rates. The curves for the three expressions ( $\mathrm{K}_{\mathrm{mtx}}, \mathrm{K}_{\mathrm{mtm}}$ and $\mathrm{K}_{\mathrm{mc}}$ ) show similar trends. $\mathrm{K}_{\mathrm{mtm}}$ and $\mathrm{K}_{\mathrm{mc}}$ trend very close to each other and are almost the same until at about the porosity value of $30 \%$ where the curves start separating from each other but consistently maintaining the same trend with each other and $\mathrm{K}_{\mathrm{mtx}}$. Reservoir quality index/porosity curves with the three expressions show the same trend for $\mathrm{RQI}_{\mathrm{aa}}, \mathrm{RQI}_{\mathrm{ab}}$ and $\mathrm{RQI} \mathrm{I}_{\mathrm{ac}}$. The three variables show almost the same pattern up to about $30 \%$ of porosity value where separation began, but still maintain the same trend. Similarly, flow zone indicator/porosity curves show almost exactly the same response like their corresponding permeability values. $\mathrm{FZI}_{\mathrm{ab}}$ and $\mathrm{FZI}_{\mathrm{ac}}$ trend very close to each other and are almost the same at the lower limits of the curves and consistently maintaining the same trend with the corresponding $\mathrm{K}_{\mathrm{mtx}}$. Most important of all are that the three expressions, each for the parameters (K, RQI and FZI) follow similar trends and within the same range up to porosity of above $35 \%$. Porosity range in sandstones is usually between 0.1 and 0.4 (10 to 40\%) [27]. 


\section{Conclusion and Recommendations}

The study involving maximising porosity in sandstone units (A Case Study of Ritchie's Block, Offshore Niger Delta), has been carried out. This work has presented alternative expressions for K, RQI and FZI, modified for use mainly in sandstone units. The evaluated reservoirs (R-M and R-N), were correlated across three wells (R$\mathrm{Da}, \mathrm{R}-\mathrm{Db}$ and $\mathrm{R}-\mathrm{Dc}$ ) and are confirmed to contain hydrocarbon. An average porosity of 0.24 was estimated for the reservoirs and it can be considered as a good value. From the combined quick-look model, the porosity of 0.24 corresponds to RQI value of $2.95 \mu \mathrm{m}$ and FZI value of $9.00 \mu \mathrm{m}$. Hence, the evaluated reservoirs can be said to have good values of RQI and FZI. This suggests that the sandstone reservoirs are well-sorted, coarse-grained with little shale contents and present good pore throats. Therefore, the pores are expected to be interconnected within these reservoirs and as such, good hydraulic conductivity and significant recovery factors are anticipated within the studied wells. Porosity range of sandstones is usually within the limits of the RQI and FZI curves presented herein. This work has showcased a way to maximise porosity based on the modified expressions.

The expressions and curves can be recommended for use in formation evaluation. The combined model can be used for the estimations of the values of RQI and FZI in sandstone units, provided porosity values derived from logs or core data are available. Similarly, if in any case, someone is interested in the use of any of the Tixier's, Timur's or Coates' idea alone, the respectively modified expressions $\left(\mathrm{K}_{\mathrm{mtx}}, \mathrm{K}_{\mathrm{mtm}}\right.$ and $\left.\mathrm{K}_{\mathrm{mc}}\right)$ with their corresponding equations for RQI and FZI and the curves are recommendable. The study has showcased porosity dependent expressions for the evaluated parameters and also provided a way of avoiding the approximation of porosity over a range of equations before the parameters herein are fully expressed. This work has emphasised the relevance of the use of the direct relationship between porosity and the evaluated parameters in the prediction of reservoirs flow units. Maximising porosity for formation evaluation as presented herein can help to minimise risk and reduce uncertainty in the evaluations of sandstone hydrocarbon reservoirs.

\section{Acknowledgement}

IEE/USP and CNPq/TWAS provided this opportunity, while Chevron Nigeria Limited (CNL) provided the data

\section{References}

[1] Schlumberger, (1989): Permeability and Productivity; Log Interpretation Principles and Application. Houston, Schlumberger Education Services. Pp 10-1 to 10-14

[2] Tiab D. and Donaldson E. C (2012): Petrophysics: Theory and Practice of Measuring Reservoir Rock and Fluid Transport Properties. Gulf Professional Publishing, Houston Texas. 950 pages.

[3] Asquith G. and Krygowski D. (2004): Basic Well Log Analysis. American Association of Petroleum Geologists, Methods in Exploration Series: American Association of Petroleum Geologists, Tulsa, Oklahoma, No 16. pp. 12-135

[4] Richardson A. M. (2013): Well Correlation and Petrophysical Analysis, a Case Study of "Rickie" Field Onshore Niger Delta. The International Journal of Engineering and Science (IJES) 2:12, pp. 94-99

[5] Bateman R. and Fessler, H. (1990): Open Hole Log Analysis and Formation Evaluation. D. Reidel Publishing Company. Pp.8.18.3

[6] Ajisafe Y.C., Ako B. D. (2013): 3-D Seismic Attributes for Reservoir Characterization of "Y" Field Niger Delta, Nigeria. IOSR Journal of Applied Geology and Geophysics 1: 2, 23-31

[7] Richardson A. M (2014): Delineation of a Productive Zone in "Abjnr" Oil Field, Niger Delta. The International Journal of Engineering and Science (IJES) 3: Pp 31-37

[8] Mian.M. A (1992): Petroleum Engineering Handbook for practising engineer. Penwell Publishing Company, Tulsa Oklahoma 74101. Vol. 1 ISBN 0-87814-370-X

[9] James C. and Oladiran O. (2010): Hydrocarbon Effect Correction on Porosity Calculation from Density Neutron Logs Using Volume of Shale in Niger Delta. Society of Petroleum Engineers SPE, SPDC Nigeria. SPE 140618 pp 1-6.

[10] Petroconsultants, (1996a): Petroleum exploration and production database: Houston, Texas, Petroconsultants, Inc. Houston, TX 77274-0619.

[11] Michele L. W. T., Ronald R. C. and Michael E. (1999): The Niger Delta Petroleum System: Niger Delta Province, Nigeria, Cameroon, and Equatorial Guinea, Africa. U.S. Department of the Interior. U.S. Geological Survey Open-File Report 99-50-H. Pp 1-44.

[12] Lehner P., and De Ruiter, P.A.C. (1977): Structural history of Atlantic Margin of Africa-American Association of Petroleum Geologists Bulletin, v. 61, pp. 961-981.

[13] Genik G.J., (1993): Petroleum Geology of the Cretaceous-Tertiary rifts basins in Niger, Chad and the Central African Republic: American Association of Petroleum Geologists Bulletin, v. 73, no. 8, pp 153-168.

[14] Rowan M.G., peel F. J and Vendeville (2004): Gravity-driven fold belts on passive margins in K.R. McClay, ed., Thrust tectonics and hydrocarbon systems: AAPG Memoir 82. Pp. 157-182

[15] Deptuck M.E., Sylvester Z., Pirmez C. and O’Byrne C. (2007): Migration-aggradation history and 3-d seismic geomorphology of submarine channels in the Pleistocene Benin-major Canyon, western niger delta slope. Marine and Petroleum Geology, Vol.24, pp. 406-433

[16] Doust H. and Omatsola, E. (1990): Niger Delta, In, Edwards, J.D., and Santogrossi, P.A., Eds., Divergent/Passive Margin Basins, AAPG Memoir 48: Tulsa, American Association of Petroleum Geologists, pp. 239-248

[17] Stacher P., (1995): Present understanding of the Niger Delta hydrocarbon habitat, in Oti, M.N., and Postma, G., eds., Geology of Deltas: Rotterdam, A.A. Balkema, p. 257-267.

[18] Freddy C. John, H. S. and Frank, B. (2005): Structural styles in the deep-water Fold and Thrust Belts of the Niger Delta. AAPG Bulletin, v. 89 , no. 6 pp. $753-780$ 
[19] Brownfield M.E., (2016): Assessment of undiscovered oil and gas resources of the Niger Delta Province, Nigeria and Cameroon Africa, in Brownfield, M.E., compiler, Geologic assessment of undiscovered hydrocarbon resources of Sub-Saharan Africa: U.S. Geological Survey Digital Data Series 69-GG, chap. 5, 20 p.,

[20] Evamy B.D., Haremboure J., Kamerling P., Knaap W.A., Molloy F.A., and Rowlands P.H. (1978): Hydrocarbon Habitat of Tertiary Niger Delta: American Association of Petroleum Geologists Bulletin, v.62, pp.277-298.

[21] Ejedawe, J.E., (1981): Patterns of Incidence of Oil Reserves in Niger Delta Basin. American Association of Petroleum Geologists, vol. 65 , pp. $1574-1585$

[22] Ekweozor, C.M. and Okoye, N.V. (1980): Petroleum Source Bed Evaluation of Tertiary Niger Delta. American Association of Petroleum Geologists Bulletin, vol. 64, pp 1251-1259.

[23] Nwachukwu, J.I. and Chukwurah, P.I. (1986): Organic Matter of Agbada Formation Niger Delta. American Association of Petroleum Geologists Bulletin. Vol 51; pp. 48-55.

[24] Weber K.J. and Daukoru, E.M., (1975): Petroleum Geology of the Niger Delta: Proceedings of the Ninth World Petroleum Congress, Volume 2. Applied Science Publishers, pp.210-221

[25] Frost, B.R. (1997): A Cretaceous Niger Delta Petroleum System, in Extended Abstracts, AAPG/ABGP Hedberg Research Symposium, Petroleum Systems of the South Atlantic Margin, November 16-19.

[26] Lambert-Aikhionbare, D.O. and Ibe, A.C. (1984): Petroleum Source Bed Evaluation of Tertiary Niger Delta - Discussion, American Association of Petroleum Geologists Bulletin, Vol 68, pp. 387-389. AAPG Wikki (2016); Porosity. http://wiki.aapg.org/Main_Page. 